\title{
Knowledge, Attitude and Practice towards Exclusive Breast Feeding among Inhabitants of Ginjo Guduru Kebele, Jimma Town, Oromia Region, Ethiopia
}

\author{
Habtamu Gebresenbet \\ Department of Biology (Human Anatomy), College of Natural and Computational Science, Bonga University, \\ Bonga, Ethiopia
}

*Corresponding Author: Habtamu Gebresenbet, Department of Biology (Human Anatomy), College of Natural and Computational Science, Bonga University, Bonga, Ethiopia P.O. Box 334.

\begin{abstract}
Appropriate feeding practices are fundamental importance for the survival, growth, development and health of infant and young children. However; exclusive breast feeding remains a challenge because of many factors. It was suggested that mother's knowledge, attitude and practice determines the effectiveness of exclusive breast feeding. This research is a cross sectional study aimed to assesses mother's knowledge, attitude and practice towards optimal breast feeding among Ginjo Guduru kebele. The survey was conducted from June 29 - July 30, 2017 from total of 315 mothers who had children under one (1) year age, 190 mothers were selected using simple random sampling. Structured pre-tested questionnaires as well as in depth interview was used to collect the data on the socio economic, demographic characteristics, knowledge attitude and practice towards exclusive breast feeding. Among mothers under studied about $73.94 \%$ had good knowledge of effective breast feeding, 63.99\% of mothers had positive attitude on effective breast feeding and $69.69 \%$ had good practice of effective breast feeding. About $24.06 \%$ of mothers had poor knowledge of effective breast feeding, about $36.11 \%$ of mothers had poor level of attitude on effective breast feeding and about $31.31 \%$ of mothers had poor practice of effective breast feeding. Health service delivery staffs Policy makers, administrators and Non-governmental organization should collaborate to draw strategies to enhance the awareness of mothers about effective breast feeding.
\end{abstract}

Keywords: Mother, breast feeding, attitude, knowledge

\section{INTRODUCTION}

The practice of lactation on the earth dates back to more than 100 million years ago and continued to the time of Homo sapiens which existed for about 40,000 years ago. Also wet nursing to lactate the child of the kings was appeared at about 200 years B.C as human being is the only in whom the natural and the most practical method of breast feeding is practiced (1). The effective breast feeding is considered as the crucial part in strategy to improve the child health. This is because malnutrition contributes to $54 \%$ of underlying cause of less than 5 years old children mortality $(4,5$, and 6$)$. Thus, breast feeding has been found as vital nourishment in strategies to improve child health. But the practice of breast feeding nowadays is getting down. This is because the use of artificial substitutes of breast milk or bottle-feeding has become wide spread to the world recently (2).
Breast feeding is nearly universal practice in Ethiopia. Studies show that about $96 \%$ of children born breast fed at some time and the proportion of children ever breastfed ranges from 93\% in Addis Ababa (20) to 99\% in Harari (25) irrespective of other back ground. Type of assistant during delivery and place of delivery have found to influence early breast feeding practices. Early initiation of breast feeding is more common among children whose mothers where assisted at delivery by a trained traditional birth attendant and among children delivered at home (3). Also it was found that the socio demographic features of population such as being dwellers of city or rural area and educational status of mothers are other variables found to affect the effective breast feeding practice. It was found that rural or illiterate mothers begin breast feeding within few hours from delivery compared to literate mothers (5). 


\subsection{Statement of the Problem}

Studies show that about 10 million children under age of five years die per a year and majorities from developing countries. In sub Saharan Africa, where almost half of all deaths in children aged less than five occurs, the decrease in mortality rates currently is sluggish and in some countries the mortality rates has even increased. As this was devastating problem, the issue has got attention so that Millennium developmental goal number four is to reduce child mortality by $2 / 3$ in 2015 (5). The causes for the change in child survival are many and include rising poverty, fragile health systems, HIV/AIDS, and malnutrition. Malnutrition is estimated to be the underlying causes of $54 \%$ of under age of 5 years children mortality $(4,5,6)$

Appropriate feeding practice is one of the fundamental importances for the survival, growth, development, health, and nutrition of infants and young children. It is argued that promotion of EBF is the most effective child health intervention currently feasible for implementation at population level in low income countries. It is also found that EBF could lower infant mortality by $13 \%$ (7). Although the role of EBF in reducing infant mortality is invaluable most women don't practice EBF for recommended 6 months $(8,9$, and 10). In Ethiopia, despite of the universal practice, breast feeding is not effective.

In Ethiopia, the increased use of formula feeding by mothers, particularly in urban and semi urban areas is because of its flexibility and ease to use, freeing them to work. Others are convinced by the aggressive marketing campaign of commercial formula companies and by the appeal or modernity that bottle feeding has come too represented. Most poor mothers have no safe water to mix with formula and have problems to properly maintain bottle sterility, and often dilute the formula to make it last longer. These actions increase the likelihood of bacterial contamination and reduce nutritional benefits of the products. $(11,12,13)$

The aim of this study is to collect baseline information about current knowledge, attitude and practice related to feeding of infants with a special focus on effective breast feeding. This study is intended to assist in designing intervention strategies to improve the practices that will be included in the result.

\subsection{Objectives of the Study}

\subsubsection{General Objective}

To assess the knowledge, attitude, practice of exclusive breast feeding among inhabitants of Ginjo Guduru Kebele.

\subsubsection{Specific Objectives}

* To determine the mothers' knowledge towards effective breast feeding.

* To identify influencing factors of the mother on breast feed of their child.

* To identify mothers' attitude towards effective breast feeding.

\section{Materials ANd Methods}

\subsection{Description of Study Area}

The study was conducted in Ginjo Guduru kebele, Jimma town. It is located $2 \mathrm{~km}$ from Jimma University, $335 \mathrm{~km}$ away from Addis Ababa, the capital city of Ethiopia. It is bordered by Mandara Kochi to North, Bacho Bore to South, Awetu mandara to west \& Ginjo to East. The climate of the kebele is Weyina Dega. The kebele's total populations are 8062 of which 4164 are males and 3898 are females. Under one year children are 315 . It has 2533 total households.

\subsection{Study Design}

A cross sectional community based survey was conducted to assess mothers KAP towards exclusive breast feeding among inhabitants of Ginjo Guduru kebele, June 29- August 1, 2017.

\subsection{Population}

Study population was all of mothers who have children less than one year in Ginjo Guduru kebele. 190 mothers who have children less than one year were representative samples.

\subsection{Sample Size and Sampling Technique}

The sample size was estimated using sample size determination formula for a single population proportion. Since there were no previous studies which estimate the prevalence of non-effective breast feeding in the area, prevalence level that estimate maximum sample size/50\%/ marginal error(d) 0.05 , non-response rates $10 \%, 95 \%$ confidence certainty and alpha 0.05 was considered, based on these assumptions, a total sample size of 190 was calculated using formula indicated below. 


$$
\mathrm{Ni}=\frac{\mathrm{Z}^{2} \mathrm{p}(1-\mathrm{P})}{\mathrm{D}^{2}}=\frac{(1.96)^{2} 0.5(0.5)}{(0.05)^{2}}=\frac{3.8416 \times 0.2^{5}}{0.0025}=384
$$

Since the total population is less than 10,000 the final sample size will be calculated by applying the population correction formula.

$$
\begin{aligned}
& \mathrm{Nf}=\underline{\mathrm{ni}} \quad \mathrm{Nf}=\text { Sample size required } \\
& 1+\underline{\mathrm{ni}} \quad \mathrm{ni}=\text { initial sample size } \\
& \mathrm{N} \quad \mathrm{N}=\text { No of mothers who have }<\text { 1years Children } \\
& \mathrm{Nf}=\underline{384}=\underline{384}=\underline{384}=\underline{384} \times \underline{315}=173 \\
& 1+\underline{384} \quad \underline{315+384} \quad \underline{699} \quad 1699 \\
& 315 \quad 315 \quad 315
\end{aligned}
$$

$173 \times 10 \%=17.3($ non- response rate of $10 \%)$

Total sample size $=173+17.3=190$

\subsection{Study Variables}

\subsubsection{Dependent Variables}

Knowledge about EBF

Attitude in relation to EBF

Practice towards EBF

\subsubsection{Independent Variables}

Age

Sex

Language

Religion

Monthly income

Occupation

Ethnicity

Marital Status

Educational status

\subsection{Questionnaires for Data Collection}

The structured questionnaires were edited by researchers from their past experiences and revised again by professional expertise (26). With certain modification in procedures made used in questionnaires development in data Collection by (26) selected questions were used to develop a scaled scoring system to categorize the level of knowledge, attitude and practices of mothers toward Effective breast feeding aspects as good or poor and the summation of mothers with correct (good) and with wrong (poor) answer for each of the knowledge, attitudinal and practice assessment questions among the study population was analyzed.

\subsection{Operational Definitions}

i. Knowledge: The information of understanding level attained through education or experience.

ii. Good knowledge: score $\geq 60 \%$ on the overall knowledge questions.

iii.Poor level of knowledge: score $<60 \%$ on the overall knowledge questions.

iv. Attitude - the way that you think and feel about something, the way that you behave towards something that shows how you think and feel.

v. Good (Positive) attitude towards attitude questions of EBF scores $>60 \%$

vi. Poor level of attitude towards attitude questions of EBF scores $<60 \%$

vii. Practice: the overt behavior, habit or custom of women.

viii.Good practice score $>60 \%$

ix. Poor practice score $<60 \%$

\subsection{Key Terms}

Complementary feeding: Provision of other foods or Liquids along with breast milk

Colostrum's: Special milk that secreted in the first 2-3 days after delivery

Early weaning: Supplementation of food in addition to breast feeding started before the age of 4 months.

Exclusive breast feeding: means optimal breastfeeding from birth to the first 6 months 
Extended Family: Families with additional members other than the mothers father, and children

Meconium: the first stools of a new born baby which are sticky and dark green.

Nuclear Family: Families made up of only parents and children.

Post-Partum: is the period of 6-12 weeks after delivery.

\subsubsection{Data Collection Procedure and Instrument}

Data was collected by trained 6th year medical student through interviewing each participant from the households to be selected using structured questionnaire.

\subsubsection{Data Processing and Analysis}

The collected data was checked for completeness of information and consistency. The data was complied, analyzed and presented using tables and percentage. A scientific calculator was used for mathematical operation of numerical variables. Computer was used for writing and editing. Chi-Square test was used to determine the level of significance and association between dependent and independent variables.

The results were compared with regional, national and WHO results.

\subsubsection{Quality Control Measure}

The questionnaire was checked for its clarity, completeness, reliability, consistency, sensitivity, time and patterns of response were used. Training was given for data collectors on the instrument and data collection procedure. Were there be any difficulties during data collection, things were explained, discussed and briefed to respondents by their mother languages. Daily monitoring of the process \& feedback on each day performance at the end of working hours was done. Then correction was made accordingly.

\section{RESUlT}

According to table.1: all the Socio-demographic feature of 190 mothers as sample population from the study area has revealed that: the minimum age and the maximum ages of population 18 and 42 are years respectively and $35.79 \%$ of respondents age ranges 25-29 years while $64.21 \%$ are distributed into different age groups. The data about child age group have shown that about $50.53 \%$ of mothers have children under age of six months and 5.26\% have children above 12 months. $44.21 \%$ of children are in the age range of 6-12 months. About $80 \%$ of women are married and $20 \%$ are divorced and widowed. About $48.95 \%$ of respondents are Muslims, $26.84 \%$ were orthodox and the remaining $20 \%$ are protestant. Majority of the respondents $(41.1 \%)$ are Oromo by ethnicity followed by $26.8 \%$ were Amhara by ethnicity. About $56.84 \%$ completed above grade ten schools. About $3.16 \%$ are illiterate and $24.21 \%$ have completed their secondary school. The rest are in primary school and preschool level. Regarding occupational status of mothers about $38.95 \%$ of them are sales and services followed by clerical and manual labors which accounts for about $24.21 \%$ and $16.84 \%$ respectively. Most of women's (30.2\%) monthly income is between 601- 1000 birr and only few $(6.9 \%)$ of women earn 1000 birr and above. About $56.84 \%$ of mothers have at most two children and about $37.94 \%$ have 3-4 children in home. The remaining $0.12 \%$ of women has greater than 7 children number per home.

Table1. Socio-demographic characteristics of mothers of child bearing age among in Ginjo Guduru kebele, Jimma town, August, 12017

\begin{tabular}{|l|l|l|}
\hline Characteristics & Frequency & Percent \\
\hline Age of mother in years & 26 & $13.66 \%$ \\
\hline $18-24$ & 68 & $35.79 \%$ \\
\hline $25-29$ & 34 & $17.88 \%$ \\
\hline $30-35$ & 32 & $16.82 \%$ \\
\hline $36-40$ & 30 & $15.85 \%$ \\
\hline $40-45$ & 190 & $100 \%$ \\
\hline Total & \multicolumn{2}{|l|}{} \\
\hline Age of child in months & 96 & $50.53 \%$ \\
\hline$<6$ & 84 & $44.21 \%$ \\
\hline $6-12$ & 10 & $5.26 \%$ \\
\hline $12-17$ & 0 & 0 \\
\hline $18-24$ & 190 & $100 \%$ \\
\hline Total & & \\
\hline
\end{tabular}


Knowledge, Attitude and Practice towards Exclusive Breast Feeding among Inhabitants of Ginjo Guduru Kebele, Jimma Town, Oromia Region, Ethiopia

\begin{tabular}{|c|c|c|}
\hline \multicolumn{3}{|l|}{ Type of family } \\
\hline Nuclear & 77 & $38.42 \%$ \\
\hline Extended & 113 & $61.58 \%$ \\
\hline Total & 190 & $100 \%$ \\
\hline \multicolumn{3}{|l|}{ Marital status } \\
\hline Single & 0 & 0 \\
\hline Married & 152 & $80 \%$ \\
\hline Divorced & 25 & $13.16 \%$ \\
\hline Widowed & 13 & $6.84 \%$ \\
\hline Total & 190 & $100 \%$ \\
\hline \multicolumn{3}{|l|}{ Religion } \\
\hline Orthodox & 51 & $26.84 \%$ \\
\hline Muslim & 93 & $48.95 \%$ \\
\hline Protestant & 38 & $20 \%$ \\
\hline Others & 8 & $4.21 \%$ \\
\hline Total & 190 & $100 \%$ \\
\hline \multicolumn{3}{|l|}{ Ethnicity } \\
\hline Oromo & 78 & $41.1 \%$ \\
\hline Amara & 51 & $26.83 \%$ \\
\hline Yem & 30 & $15.78 \%$ \\
\hline Kafa & 24 & $12.62 \%$ \\
\hline Others & 7 & $3.67 \%$ \\
\hline Total & 190 & $100 \%$ \\
\hline \multicolumn{3}{|l|}{ Educational status } \\
\hline Illiterate & 6 & $3.16 \%$ \\
\hline Preschool & 3 & $1.58 \%$ \\
\hline Grade1- 8 & 27 & $14.21 \%$ \\
\hline Gras 9- 10 & 46 & $24.21 \%$ \\
\hline Above grade 10 & 108 & $56.84 \%$ \\
\hline Total & 190 & $100 \%$ \\
\hline Professionals & 11 & $5.79 \%$ \\
\hline Clerical & 46 & $24.21 \%$ \\
\hline Sales and services & 74 & $38.95 \%$ \\
\hline Labors & 32 & $16.84 \%$ \\
\hline Agriculture & 18 & $9.47 \%$ \\
\hline Others & 9 & $4.74 \%$ \\
\hline Total & 190 & $100 \%$ \\
\hline \multicolumn{3}{|l|}{ Monthly income } \\
\hline$<200 \mathrm{ETB}$ & 46 & $24.4 \%$ \\
\hline 200- 400 ETB & 48 & $24.6 \%$ \\
\hline 401- 600 ETB & 26 & $13.9 \%$ \\
\hline 601- 1000 ETB & 58 & $30.2 \%$ \\
\hline$>1000 \mathrm{ETB}$ & 12 & $6.9 \%$ \\
\hline Total & 190 & $100 \%$ \\
\hline \multicolumn{3}{|c|}{ Number of children } \\
\hline $1-2$ & 108 & $56.84 \%$ \\
\hline $3-4$ & 72 & $37.94 \%$ \\
\hline $5-6$ & 8 & $4.2 \%$ \\
\hline$>7$ & 2 & $0.12 \%$ \\
\hline Total & 190 & $100 \%$ \\
\hline
\end{tabular}

As depicted in Table 2. below, among women of child bearing ages, about $92.63 \%$ had practiced breast feeding. The remaining women's have no a practice. About $74.74 \%$ of mothers had health education while the remaining mothers have no health education yet. The mass media have played a greatest role in awareness creation that account for $49.47 \%$ whereas books and information from health institution accounts for about $12.63 \%$ and $11.58 \%$ respectively. Majority of mothers evaluated their general health status as good and very good accounting for $44.21 \%$ and $33.16 \%$ respectively. About $3.16 \%$ of mothers evaluated themselves as very bad. 
Knowledge, Attitude and Practice towards Exclusive Breast Feeding among Inhabitants of Ginjo Guduru Kebele, Jimma Town, Oromia Region, Ethiopia

Table2. Exclusive breast feeding practice of child bearing aged mothers and influencing Factors in Ginjo Guduru, Jimma town, August 2017

\begin{tabular}{|c|c|c|}
\hline Characteristics & Frequency & Percent \\
\hline \multicolumn{3}{|c|}{ Have you ever practiced breast feeding } \\
\hline Yes & 176 & $92.63 \%$ \\
\hline No & 14 & $7.37 \%$ \\
\hline Total & 190 & $100 \%$ \\
\hline \multicolumn{3}{|c|}{ Have you ever get any health education } \\
\hline Yes & 142 & $74.74 \%$ \\
\hline No & 48 & $25.26 \%$ \\
\hline Total & 190 & $100 \%$ \\
\hline \multicolumn{3}{|c|}{ If yes can you mention the source of information } \\
\hline Health institution & 22 & $11.58 \%$ \\
\hline Mass media & 94 & $49.47 \%$ \\
\hline Books & 24 & $12.63 \%$ \\
\hline Others & 2 & $1.05 \%$ \\
\hline Total & 142 & $74.74 \%$ \\
\hline \multicolumn{3}{|c|}{ How do you evaluate your general health status } \\
\hline Very good & 63 & $33.16 \%$ \\
\hline Good & 84 & $44.21 \%$ \\
\hline Bad & 37 & $19.47 \%$ \\
\hline Very bad & 6 & $3.16 \%$ \\
\hline Total & 190 & $100 \%$ \\
\hline
\end{tabular}

As presented in Table 3, the knowledge assessment shows that: about $92.63 \%$ of them knew the importance of breast feeding and of these $81.05 \%$ of mothers knew that breast milk alone is important for the new born. The importance of water and butter are suggested by $10.53 \%$ and $6.32 \%$ of mothers respectively. Concerning the duration of exclusive breast feeding about $82.1 \%$ know that child should be breast fed from 4-6 months while 10\% know the duration to be 4 months and the remaining prefer more than 6 months. About $92.63 \%$ of the mothers had knowledge on breast feeding as it did not cause harm to the child. The reaming said it harm the child. Concerning the knowledge of bottle feeding $46.84 \%$ of the mothers said it did not cause harm to the child, $53.16 \%$ knew bottle feeding cause harm to the child. Concerning to the time to start complementary feeding about $81.05 \%$ did not start before four months. About $18.95 \%$ started before four months. The reason they started before four months as they said was their breast feeding was not sufficient alone in about $8.95 \%$, the others said breast feeding was not sufficient in about $4.74 \%$. $3.68 \%$ of mothers said due to child refusal. Regarding to the duration of exclusive breast feeding $55.26 \%$ of the mothers exclusively breast feed for six months. About $15.79 \%$ exclusively breast feed for four months.

Table3. Knowledge of mothers of child bearing age among Ginjo Guduru kebele, Jimma town, August 1, 2017

\begin{tabular}{|l|l|l|}
\hline Characteristics & Frequency & Percent \\
\hline Do you know the importance of breast feeding? & 176 & $92.63 \%$ \\
\hline Yes & 14 & $7.37 \%$ \\
\hline No & 190 & $100 \%$ \\
\hline Total & 154 & $81.05 \%$ \\
\hline Which one of the following do you think is important for the new born? & 12 & $6.32 \%$ \\
\hline Breast milk only & 12 & $10.53 \%$ \\
\hline Butter & 20 & $2.1 \%$ \\
\hline Water & 4 & $100 \%$ \\
\hline Other & 190 & \multicolumn{2}{l|}{} \\
\hline Total & \multicolumn{2}{l}{} \\
\hline For how long should an infant EBF only? & 19 & $10 \%$ \\
\hline$<4$ month & 156 & $82.1 \%$ \\
\hline $4-6$ month & 15 & $7.9 \%$ \\
\hline$>6$ months & 190 & $100 \%$ \\
\hline Total & 14 & $7.37 \%$ \\
\hline Do you think breast feeding harm the child? & 14 \\
\hline Yes
\end{tabular}


Knowledge, Attitude and Practice towards Exclusive Breast Feeding among Inhabitants of Ginjo Guduru Kebele, Jimma Town, Oromia Region, Ethiopia

\begin{tabular}{|c|c|c|}
\hline No & 176 & $92.63 \%$ \\
\hline Total & 190 & $100 \%$ \\
\hline \multicolumn{3}{|c|}{ Do you think bottle feeding is dangerous for the child? } \\
\hline Yes & 89 & $46.84 \%$ \\
\hline No & 101 & $53.16 \%$ \\
\hline Total & 190 & $100 \%$ \\
\hline \multicolumn{3}{|c|}{ Did you start complementary feeding before 4 months? } \\
\hline Yes & 36 & $18.95 \%$ \\
\hline No & 154 & $81.05 \%$ \\
\hline Total & 190 & 100 \\
\hline \multicolumn{3}{|l|}{ If yes what is possible reason? } \\
\hline My breast milk is not sufficient & 9 & $4.74 \%$ \\
\hline I do not think breast milk alone is sufficient & 17 & $8.95 \%$ \\
\hline Child refusal & 7 & $3.68 \%$ \\
\hline Other & 3 & $1.58 \%$ \\
\hline Total & 36 & $18.95 \%$ \\
\hline \multicolumn{3}{|c|}{ For how long should a baby breast feed exclusively? } \\
\hline One month & 10 & $5.26 \%$ \\
\hline Two month & 18 & $9.47 \%$ \\
\hline Three month & 23 & $12.11 \%$ \\
\hline Four month & 30 & $15.79 \%$ \\
\hline Six months & 105 & $55.26 \%$ \\
\hline Others & 4 & $2.11 \%$ \\
\hline Total & 190 & $100 \%$ \\
\hline \multicolumn{3}{|c|}{ What do you prefer to feed your baby for the first 4 months? } \\
\hline Breast milk alone & 106 & $55.79 \%$ \\
\hline Breast milk with formula & 14 & $7.37 \%$ \\
\hline Breast milk with cow milk & 62 & $32.63 \%$ \\
\hline Others & 8 & $4.21 \%$ \\
\hline Total & 190 & $100 \%$ \\
\hline \multicolumn{3}{|c|}{ Do you feel that EBF for 6 months infant has advantageous? } \\
\hline Agree & 111 & $58.42 \%$ \\
\hline Neutral & 51 & $26.84 \%$ \\
\hline Disagree & 28 & $14.74 \%$ \\
\hline Total & 190 & $100 \%$ \\
\hline \multicolumn{3}{|c|}{ Do you believe that the firs milk (colostrums) should be discarded? } \\
\hline Agree & 18 & $9.47 \%$ \\
\hline Neutral & 48 & $25.27 \%$ \\
\hline Disagree & 124 & $65.26 \%$ \\
\hline Total & 190 & $100 \%$ \\
\hline
\end{tabular}

Concerning the attitude of mothers towards KAP of exclusively breast feeding in (Table 4) as usual, 190 of child bearing age women interviewed. Among these $55.79 \%$ preferred to feed their babies in the first four months with breast milk alone. About $32.63 \%$ prefer to feed with breast milk and cow milk together. The remaining $7.37 \%$ preferred to feed with breast milk and formula milk. $58.42 \%$ of mothers agreed as exclusively breast feeding for the first six months was advantageous for the baby's. The others had ideas of neutral and disagree which accounts for $26.84 \%$ and $14.74 \%$ respectively. Concerning colostrums about $65.26 \%$ said colostrum should not discard and $9.47 \%$ agreed on the ideas, while the remaining ones were neutral. About $55.26 \%$ of mothers said that exclusively breast feeding is sufficient for the baby in the first four months. Other said it was not sufficient as cow milk and formula milk which accounts for about $16.84 \%$. About $93.16 \%$ of the mothers said their babies' breast fed as frequent as they need and the remaining said no.

Regarding attitude of bottle feeding about $64.74 \%$ of mothers said it was useful if breastfed was impossible, $22.11 \%$ of mother said it was useful we there breast fed or not and the remain told it was not important. Regarding opinion of mothers on breast feeding as mothers of today about $54.21 \%$ of mothers said it was natural and appropriate, about $23.68 \%$ said it was outmoded and about $13.16 \%$ told it disfigures the women's shape. About $6.84 \%$ said it looks him/her old. 
Knowledge, Attitude and Practice towards Exclusive Breast Feeding among Inhabitants of Ginjo Guduru Kebele, Jimma Town, Oromia Region, Ethiopia

Table4. Attitudes of mothers of child bearing age in Ginjo Guduru kebele, Jimma town, July 2017

\begin{tabular}{|c|c|c|}
\hline \multicolumn{2}{|l|}{ Characteristics } & Percent \\
\hline \multicolumn{3}{|l|}{ What is your opinion about EBF in the first 4- months? } \\
\hline \multicolumn{2}{|l|}{ It is useful sufficient for the baby } & $55.26 \%$ \\
\hline \multicolumn{2}{|l|}{ It is useful but not sufficient alone } & $15.79 \%$ \\
\hline \multicolumn{2}{|l|}{ It is useful but not as much as formula or cow milk } & $16.84 \%$ \\
\hline \multicolumn{2}{|l|}{ It is not advantage at all } & $8.95 \%$ \\
\hline \multicolumn{2}{|l|}{ I don't care whether I breast feed or not } & $3.16 \%$ \\
\hline \multicolumn{2}{|l|}{ Total } & $100 \%$ \\
\hline \multicolumn{3}{|c|}{ Do you believe that your baby breastfed as frequent as he/she needs? } \\
\hline \multicolumn{2}{|l|}{ Yes } & $93.16 \%$ \\
\hline \multicolumn{2}{|l|}{ No } & $6.84 \%$ \\
\hline \multicolumn{2}{|l|}{ Total } & $100 \%$ \\
\hline \multicolumn{3}{|l|}{ What is your suggestion about bottle feeding? } \\
\hline \multicolumn{2}{|l|}{ Useful whether breastfeed or not } & $22.11 \%$ \\
\hline \multicolumn{2}{|l|}{ Useful when breast feeding is impossible } & $64.74 \%$ \\
\hline \multicolumn{2}{|l|}{ Dangerous should not used at all } & $8.94 \%$ \\
\hline \multicolumn{2}{|l|}{ Others } & $4.21 \%$ \\
\hline \multicolumn{2}{|l|}{ Total } & $100 \%$ \\
\hline \multicolumn{3}{|c|}{ What is your opinion on breast feeding as mothers today? } \\
\hline \multicolumn{2}{|l|}{ It is outmoded } & $23.68 \%$ \\
\hline \multicolumn{2}{|l|}{ It disfigures women's shape } & $13.16 \%$ \\
\hline \multicolumn{2}{|l|}{ It makes her look old } & $6.84 \%$ \\
\hline \multicolumn{2}{|l|}{ It is natural and appropriate today } & $54.21 \%$ \\
\hline \multicolumn{2}{|l|}{ Others } & $2.11 \%$ \\
\hline Total & 190 & $100 \%$ \\
\hline $\begin{array}{l}\text { Concerning practice of KAP on exclusive breast } \\
\text { feeding of mothers of childbearing age in the } \\
\text { kebeles (Table 5), among } 190 \text { about } 85.26 \% \% \\
\text { started to breast feed within one hour of } \\
\text { delivery, where as } 10.53 \% \text { started after one } \\
\text { hour. About } 47.9 \% \text { of the woman breast fed } \\
\text { their child } 8-10 \text { times per a day. Whereas } \\
33.16 \% \text { breastfed for greater than } 10 \text { times per a } \\
\text { day. The remaining one breast fed their child } \\
\text { less than } 8 \text { times per a day. About } 92.11 \% \\
\text { exclusively breastfed their babies. Among these } \\
84.21 \% \text { exclusively breastfed their babies for } \\
\text { the first six months and about } 5.79 \% \text { of the } \\
\text { mothers breast fed for greater than six months. } \\
\text { Regarding colostrum about } 76.84 \% \text { of mothers } \\
\text { gave colostrum to their baby, the remaining } \\
\text { didn't do that. The reason they didn't gave is, } \\
\text { because it seems like dirty and pus in about }\end{array}$ & $\begin{array}{l}13.68 \% \text { of mothers, the elder chil } \\
\text { no opinion which accounts for ab } \\
1.05 \% \text { respectively. The practice } \\
\text { nutrient for the infant was in } \\
\text { breast milk, } 21.58 \% \text { water, } 11.0 \\
6.84 \% \text { butter. Regarding the time } \\
\text { breast feeding about } 54.74 \% \text { of th } \\
\text { from } 19-24 \text { months. About } 24.7 \\
\text { said from } 13-18 \text { months. The ren } \\
12 \text { months and up to } 6 \text { months } \\
\text { for } 12.63 \% \text { and } 5.79 \% \text { respective } \\
\text { they stopped breast feeding } \\
51.59 \% \text { due to it was the time } \\
\text { feeding, in about } 17.37 \% \text { thei } \\
\text { eating well, } 11.05 \% \text { was due to de } \\
\text { of their milk. The others told bc } \\
\text { were sick and took drugs in a }\end{array}$ & $\begin{array}{l}\text { d got sick and } \\
\text { out } 7.37 \% \text { and } \\
\text { of giving first } \\
\text { about } 56.84 \% \\
5 \% \text { sugar and } \\
\text { of cessation of } \\
\text { e mothers said } \\
1 \% \text { of mothers } \\
\text { laining said } 7- \\
\text { hich accounts } \\
\text { ly. The reason } \\
\text { vas in about } \\
\text { to stop breast } \\
\text { baby didn't } \\
\text { crease in flow } \\
\text { cause of they } \\
\text { aout } 7.9 \% \text {, in } \\
\text { ant. }\end{array}$ \\
\hline
\end{tabular}

Table5. Practice of exclusive breast feeding mothers of child bearing age in Ginjo Guduru kebele, Jimma town, August 1, 2017

\begin{tabular}{|c|c|c|}
\hline Variables & Frequency & Percent \\
\hline \multicolumn{3}{|c|}{ When did you start breast feeding after delivery } \\
\hline Within one hour & 162 & $85.26 \%$ \\
\hline After one hour & 20 & $10.53 \%$ \\
\hline Others & 8 & $4.21 \%$ \\
\hline Total & 190 & $100 \%$ \\
\hline \multicolumn{3}{|c|}{ Daily frequency of braest feeding? } \\
\hline$<8$ times & 36 & $18.95 \%$ \\
\hline 8 - 10 times & 91 & $47.9 \%$ \\
\hline$>10$ times & 63 & $33.16 \%$ \\
\hline
\end{tabular}


Knowledge, Attitude and Practice towards Exclusive Breast Feeding among Inhabitants of Ginjo Guduru Kebele, Jimma Town, Oromia Region, Ethiopia

\begin{tabular}{|c|c|c|}
\hline Total & 190 & $100 \%$ \\
\hline \multicolumn{3}{|l|}{ Do you breast feed your baby exclusively? } \\
\hline Yes & 175 & $92.11 \%$ \\
\hline No & 15 & $7.89 \%$ \\
\hline Total & 190 & $100 \%$ \\
\hline \multicolumn{3}{|l|}{ If yes how long? } \\
\hline within the first 6 months & 160 & $84.21 \%$ \\
\hline$>6$ months & 11 & $5.79 \%$ \\
\hline Others & 4 & $2.11 \%$ \\
\hline Total & 175 & $92.11 \%$ \\
\hline \multicolumn{3}{|l|}{ Did you give colostrums to your baby } \\
\hline Yes & 146 & $76.84 \%$ \\
\hline No & 44 & $23.16 \%$ \\
\hline Total & 190 & $100 \%$ \\
\hline \multicolumn{3}{|c|}{ If your answer to question above is no what is your reason? } \\
\hline I have no white milk & 0 & \\
\hline First milk is dirty, like pus & 26 & $13.68 \%$ \\
\hline Every baby says it should not be given & 0 & \\
\hline Baby didn't like it & 0 & \\
\hline My elder children become sick & 14 & $7.37 \%$ \\
\hline I don’t know, have no opinion & 2 & $1.05 \%$ \\
\hline Total & 44 & $23.16 \%$ \\
\hline \multicolumn{3}{|l|}{ What was the first nutrient given for the infant? } \\
\hline Sugar & 21 & $11.05 \%$ \\
\hline Butter & 13 & $6.84 \%$ \\
\hline Water & 41 & $21.58 \%$ \\
\hline Breast milk & 108 & $56.84 \%$ \\
\hline Other & 7 & $3.69 \%$ \\
\hline Total & 190 & $100 \%$ \\
\hline
\end{tabular}

Table6. The practice of breast feeding in women of child bearing age in Ginjo Guduru kebele, Jimma town, August 2017

\begin{tabular}{|c|c|c|}
\hline Characteristics & Frequency & Percent \\
\hline \multicolumn{3}{|c|}{ What is the cessation time of breast feeding? } \\
\hline $0-6$ months & 11 & $5.79 \%$ \\
\hline 7- 12 months & 24 & $12.63 \%$ \\
\hline 13- 18 months & 47 & $24.74 \%$ \\
\hline 19- 24 months & 104 & $54.74 \%$ \\
\hline Others & 4 & $2.1 \%$ \\
\hline Total & 190 & $100 \%$ \\
\hline \multicolumn{3}{|c|}{ What is the reason for cessation of breast feeding of your child? } \\
\hline I get pregnant & 11 & $5.79 \%$ \\
\hline I become sick and took a medicine & 15 & $7.9 \%$ \\
\hline It was adequate time to stop & 98 & $51.59 \%$ \\
\hline My baby had not eating meals & 33 & $17.37 \%$ \\
\hline My milk is not good for my baby & 10 & $5.26 \%$ \\
\hline The flow of my milk is starred & 21 & $11.05 \%$ \\
\hline Other & 2 & $1.05 \%$ \\
\hline Total & 190 & $100 \%$ \\
\hline
\end{tabular}

Table 7. Shows that: type of family child bearing age of mothers, educational status and occupation has significant association with knowledge of exclusive breast feeding having Pvalue $<0.05$. In addition to these, child age, ethnicity, religion, monthly income, no of children and marital status have no association with the knowledge toward EBF with P-value > 0.05 
Knowledge, Attitude and Practice towards Exclusive Breast Feeding among Inhabitants of Ginjo Guduru Kebele, Jimma Town, Oromia Region, Ethiopia

Table7. Association between socio-demographic factors and knowledge of mothers towards EBF in Ginjo Guduru kebeles, Jimma town, August 1, 2017

\begin{tabular}{|c|c|c|c|c|c|}
\hline \multirow[t]{2}{*}{ Socio-demographic factors } & & \multicolumn{2}{|c|}{ Knowledge } & \multirow[t]{2}{*}{ Total } & \multirow[t]{2}{*}{$\mathrm{X}^{2} \mathrm{p}$ value } \\
\hline & & Good knowledge & Poor knowledge & & \\
\hline \multirow{6}{*}{ Age of the mother in years } & $18-24$ & 22 & 4 & 26 & \multirow{6}{*}{$\begin{array}{c}X^{2}=26.8 \\
P \text { value }=0.000\end{array}$} \\
\hline & $25-29$ & 59 & 9 & 68 & \\
\hline & $30-35$ & 27 & 7 & 34 & \\
\hline & $36-40$ & 24 & 8 & 32 & \\
\hline & $40-45$ & 12 & 18 & 30 & \\
\hline & Total & 144 & 46 & 190 & \\
\hline \multirow[t]{4}{*}{ Age of the child in months } & $<6$ & 66 & 30 & 96 & \multirow{4}{*}{$\begin{array}{c}\mathrm{X}^{2}=11.9 \\
\mathrm{P} \text { value }=0.113\end{array}$} \\
\hline & $6-12$ & 73 & 11 & 84 & \\
\hline & $12-17$ & 5 & 5 & 10 & \\
\hline & Total & 144 & 46 & 190 & \\
\hline \multirow[t]{3}{*}{ Type of family } & Nuclear & 47 & 30 & 77 & \multirow{3}{*}{$\begin{array}{c}X^{2}=15.4 \\
P \text { value }=0.000\end{array}$} \\
\hline & Extended & 97 & 16 & 113 & \\
\hline & Total & 144 & 46 & 190 & \\
\hline \multirow[t]{5}{*}{ Marital status } & Single & 0 & 0 & 0 & \multirow{5}{*}{$\begin{array}{c}X^{2}=110 \\
P \text { value }=0.567\end{array}$} \\
\hline & Married & 140 & 12 & 152 & \\
\hline & Divorced & 3 & 22 & 25 & \\
\hline & Widow & 1 & 12 & 13 & \\
\hline & Total & 144 & 46 & 190 & \\
\hline \multirow[t]{5}{*}{ Religion } & Orthodox & 42 & 9 & 51 & \multirow{5}{*}{$\begin{array}{c}X^{2}=119 \\
P \text { value }=0.097\end{array}$} \\
\hline & Muslim & 74 & 19 & 93 & \\
\hline & Protestant & 27 & 11 & 38 & \\
\hline & Others & 1 & 7 & 8 & \\
\hline & Total & 144 & 46 & 190 & \\
\hline \multirow[t]{6}{*}{ Ethinicity } & Oromo & 67 & 11 & 78 & \multirow{6}{*}{$\begin{array}{c}X^{2}=110 \\
P \text { value }=0.09\end{array}$} \\
\hline & Amhara & 35 & 12 & 51 & \\
\hline & Yem & 20 & 10 & 30 & \\
\hline & Kefa & 16 & 8 & 24 & \\
\hline & Others & 2 & 5 & 7 & \\
\hline & Total & 144 & 46 & 190 & \\
\hline \multirow[t]{6}{*}{ Educational status } & Illiterate & 1 & 5 & 6 & \multirow{6}{*}{$\begin{array}{c}\mathrm{X}^{2}=19.2 \\
\mathrm{P} \text { value }=0.001\end{array}$} \\
\hline & Preschool & 1 & 2 & 3 & \\
\hline & Grade1- 8 & 17 & 10 & 27 & \\
\hline & Grade 9-10 & 37 & 9 & 46 & \\
\hline & Above grade 10 & 88 & 20 & 108 & \\
\hline & Total & 144 & 46 & 190 & \\
\hline \multirow[t]{7}{*}{ Occupation } & Professionals & 7 & 4 & 11 & $X^{2}=22.4$ \\
\hline & Clerical & 29 & 17 & 46 & $\mathrm{P}$ value $=0.000$ \\
\hline & Sales and services & 68 & 6 & 74 & \\
\hline & Manual labors & 25 & 7 & 32 & \\
\hline & Agriculture & 9 & 9 & 18 & \\
\hline & Other & 6 & 3 & 9 & \\
\hline & Total & 144 & 46 & 190 & \\
\hline Monthly in come & $<200$ & 27 & 19 & 46 & $X^{2}=11.6$ \\
\hline & $200-400$ & 39 & 9 & 48 & $\mathrm{P}$ value $=0.132$ \\
\hline & $401-600$ & 19 & 7 & 26 & \\
\hline & $601-1000$ & 50 & 8 & 58 & \\
\hline & $>1000$ & 9 & 3 & 12 & \\
\hline & Total & 144 & 46 & 190 & \\
\hline Number of children & $1-2$ & 87 & 21 & 108 & $\mathrm{X}^{2}=18.9$ \\
\hline & $3-4$ & 55 & 17 & 72 & $\mathrm{P}$ value $=0.089$ \\
\hline & $5-6$ & 2 & 6 & 8 & \\
\hline & $>7$ & 0 & 2 & 2 & \\
\hline & Total & 144 & 46 & 190 & \\
\hline
\end{tabular}


Knowledge, Attitude and Practice towards Exclusive Breast Feeding among Inhabitants of Ginjo Guduru Kebele, Jimma Town, Oromia Region, Ethiopia

As presented on table. 8, except the occupation of mothers which significantly affects the attitude of mothers toward EBF, no other socio- demographic features have association with the attitude toward EBF.

Table8. Association between socio-demographic factors and Attitude of mothers towards EBF in Ginjo Guduru kebeles, Jimma town, August 1, 2017

\begin{tabular}{|c|c|c|c|c|c|}
\hline \multirow{2}{*}{\multicolumn{2}{|c|}{ Socio-demographic factors }} & \multicolumn{2}{|c|}{ level of attitude } & \multirow[t]{2}{*}{ Total } & \multirow[t]{2}{*}{$\mathrm{X}^{2}$ p value } \\
\hline & & Positive & \multirow{2}{*}{$\frac{\text { Poor }}{10}$} & & \\
\hline \multirow[t]{6}{*}{ Age of the mother in years } & $18-24$ & 16 & & 26 & \multirow{6}{*}{$\begin{array}{c}\mathrm{X}^{2}=2.06 \\
\mathrm{P} \text { value }=0.725\end{array}$} \\
\hline & $25-29$ & 44 & 24 & 68 & \\
\hline & $30-35$ & 23 & 11 & 34 & \\
\hline & $36-40$ & 22 & 10 & 32 & \\
\hline & $40-45$ & 16 & 14 & 30 & \\
\hline & Total & 121 & 69 & 190 & \\
\hline \multirow[t]{4}{*}{ Age of the child in months } & $<6$ & 64 & 32 & 96 & \multirow{4}{*}{$\begin{array}{c}\mathrm{X}^{2}=1.29 \\
\mathrm{P} \text { value }=0.524\end{array}$} \\
\hline & 6- 12 & 52 & 32 & 84 & \\
\hline & $12-17$ & 5 & 5 & 10 & \\
\hline & Total & 121 & 69 & 190 & \\
\hline \multirow[t]{3}{*}{ Type of family } & Nuclear & 40 & 37 & 77 & \multirow{3}{*}{$\begin{array}{c}X^{2}=7.71 \\
\text { P value }=0.005\end{array}$} \\
\hline & Extended & 81 & 32 & 113 & \\
\hline & Total & 121 & 69 & 190 & \\
\hline \multirow[t]{5}{*}{ Marital status } & Single & 0 & 0 & 0 & \multirow{5}{*}{$\begin{array}{c}X^{2}=0.245 \\
P \text { value }=0.885\end{array}$} \\
\hline & Married & 96 & 56 & 152 & \\
\hline & Divorced & 17 & 8 & 25 & \\
\hline & Widow & 8 & 5 & 13 & \\
\hline & Total & 121 & 69 & 190 & \\
\hline \multirow[t]{5}{*}{ Religion } & Orthodox & 39 & 12 & 51 & \multirow{5}{*}{$\begin{array}{c}X^{2}=1.48 \\
P \text { value }=0.686\end{array}$} \\
\hline & Muslim & 53 & 40 & 93 & \\
\hline & Protestant & 23 & 15 & 38 & \\
\hline & \begin{tabular}{|l|} 
Others \\
\end{tabular} & 6 & 2 & 8 & \\
\hline & Total & 121 & 69 & 190 & \\
\hline \multirow[t]{6}{*}{ Ethnicity } & Oromo & 46 & 32 & 78 & \multirow{6}{*}{$\begin{array}{c}X^{2}=110 \\
P \text { value }=0.456\end{array}$} \\
\hline & Amhara & 35 & 16 & 51 & \\
\hline & Yem & 19 & 11 & 30 & \\
\hline & Kefa & 16 & 8 & 24 & \\
\hline & \begin{tabular}{|l|} 
Others \\
\end{tabular} & 5 & 2 & 7 & \\
\hline & Total & 121 & 69 & 190 & \\
\hline \multirow[t]{6}{*}{ Educational status } & Illiterate & 2 & 4 & 6 & \multirow{6}{*}{$\begin{array}{c}X^{2}=4.46 \\
P \text { value }=0.347\end{array}$} \\
\hline & Preschool & 1 & 2 & 3 & \\
\hline & Grade 1-8 & 19 & 8 & 27 & \\
\hline & Grade9- 10 & 28 & 18 & 46 & \\
\hline & Above grade 10 & 71 & 37 & 108 & \\
\hline & Total & 121 & 69 & 190 & \\
\hline Occupations & Professionals & 8 & 4 & 11 & \\
\hline & Clerical & 34 & 13 & 46 & $X^{2}=21.8$ \\
\hline & Sales and sevices & 56 & 18 & 74 & $\mathrm{P}$ value $=0.001$ \\
\hline & Manual labours & 12 & 22 & 32 & \\
\hline & Agriculture & 8 & 10 & 18 & \\
\hline & Others & 7 & 2 & 9 & \\
\hline & Total & 121 & 69 & 190 & \\
\hline Monthly income & $<200$ & 26 & 20 & 46 & \\
\hline & $200-400$ & 29 & 19 & 48 & $X^{2}=3.25$ \\
\hline & $401-600$ & 16 & 10 & 26 & $\mathrm{P}$ value $=0.517$ \\
\hline & 601- 1000 & 42 & 16 & 58 & \\
\hline & $>1000$ & 8 & 4 & 12 & \\
\hline & Total & 121 & 69 & 190 & \\
\hline Number of children & $1-2$ & 79 & 29 & 108 & \\
\hline & $3-4$ & 40 & 32 & 72 & $X^{2}=14.9$ \\
\hline & $5-7$ & 2 & 6 & 8 & $\mathrm{P}$ value $=0.122$ \\
\hline
\end{tabular}


Knowledge, Attitude and Practice towards Exclusive Breast Feeding among Inhabitants of Ginjo Guduru Kebele, Jimma Town, Oromia Region, Ethiopia

\begin{tabular}{|l|l|l|l|}
\hline$>7$ & 0 & 2 & 2 \\
\hline Total & 121 & 69 & 190 \\
\hline
\end{tabular}

The age and educational status of mothers in the study area have significant effect on practice of association with EBF practice as presented by table.9.

EBF. Other socio-demographic features have no

Table9. Association between socio-demographic factors and practice of mothers towards EBF in Ginjo Guduru kebeles, Jimma town, August 1, 2017

\begin{tabular}{|c|c|c|c|c|c|}
\hline \multirow[t]{2}{*}{ Socio-demographic factors } & & \multicolumn{2}{|c|}{ Practice } & \multirow[t]{2}{*}{ Total } & \multirow[t]{2}{*}{$\mathrm{X}^{2} \mathrm{p}$ value } \\
\hline & & Good & Poor & & \\
\hline \multirow{6}{*}{ Age of the mother in years } & $18-24$ & 16 & 10 & 26 & \multirow{6}{*}{$\begin{array}{c}X^{2}=12.0 \\
P \text { value }=0.017\end{array}$} \\
\hline & $25-30$ & 53 & 15 & 68 & \\
\hline & $30-35$ & 27 & 7 & 34 & \\
\hline & $36-40$ & 22 & 10 & 32 & \\
\hline & $40-45$ & 14 & 16 & 30 & \\
\hline & Total & 132 & 58 & 190 & \\
\hline \multirow[t]{4}{*}{ Age of the child in months } & $<6$ & 73 & 23 & 96 & \multirow{4}{*}{$\begin{array}{c}X^{2}=3.99 \\
P \text { value }=0.136\end{array}$} \\
\hline & $6-12$ & 53 & 31 & 84 & \\
\hline & $12-17$ & 6 & 4 & 10 & \\
\hline & Total & 132 & 58 & 190 & \\
\hline \multirow[t]{3}{*}{ Type of family } & Nuclear & 52 & 25 & 77 & \multirow{3}{*}{$\begin{array}{c}X^{2}=0.230 \\
P \text { value }=0.631\end{array}$} \\
\hline & Extended & 80 & 33 & 113 & \\
\hline & Total & 132 & 58 & 190 & \\
\hline \multirow{5}{*}{ Marital status } & Single & 0 & 0 & 0 & \multirow{5}{*}{$\begin{array}{c}X^{2}=0.918 \\
P \text { value }=0.632\end{array}$} \\
\hline & Married & 108 & 44 & 152 & \\
\hline & Divorced & 16 & 9 & 25 & \\
\hline & Widow & 8 & 5 & 13 & \\
\hline & Total & 132 & 58 & 190 & \\
\hline \multirow[t]{5}{*}{ Religion } & Orthodox & 39 & 12 & 51 & \multirow{5}{*}{$\begin{array}{c}X^{2}=3.21 \\
\text { P value }=0.361\end{array}$} \\
\hline & Muslim & 59 & 34 & 93 & \\
\hline & Protestant & 28 & 10 & 38 & \\
\hline & Others & 6 & 2 & 8 & \\
\hline & Total & 132 & 58 & 190 & \\
\hline \multirow[t]{6}{*}{ Ethnicity } & Oromo & 58 & 20 & 78 & \multirow{6}{*}{$\begin{array}{c}\mathrm{X}^{2}=2.73 \\
\mathrm{P} \text { value }=0.604\end{array}$} \\
\hline & Amhara & 31 & 20 & 51 & \\
\hline & Yem & 21 & 9 & 30 & \\
\hline & Kefa & 17 & 7 & 24 & \\
\hline & Others & 5 & 2 & 7 & \\
\hline & Total & 132 & 58 & 190 & \\
\hline \multirow[t]{6}{*}{ Education } & Illiterate & 1 & 5 & 6 & \multirow{6}{*}{$\begin{array}{c}\mathrm{X}^{2}=12.8 \\
\mathrm{P} \text { value }=0.012\end{array}$} \\
\hline & Preschool & 1 & 2 & 3 & \\
\hline & Grade 1-8 & 16 & 11 & 27 & \\
\hline & Grade 9-10 & 36 & 10 & 46 & \\
\hline & Above grade 10 & 77 & 31 & 108 & \\
\hline & Total & 132 & 58 & 190 & \\
\hline \multirow[t]{7}{*}{ Occupation } & Professionals & 7 & 4 & 11 & \multirow{7}{*}{$\begin{array}{c}X^{2}=3.72 \\
P \text { value }=0.591\end{array}$} \\
\hline & Clerical & 35 & 11 & 46 & \\
\hline & Sales and services & 54 & 20 & 74 & \\
\hline & Manual labors & 19 & 13 & 32 & \\
\hline & Agriculture & 11 & 7 & 18 & \\
\hline & Others & 6 & 3 & 9 & \\
\hline & Total & 132 & 58 & 190 & \\
\hline \multirow[t]{6}{*}{ Monthly income } & $<200$ & 29 & 17 & 46 & \\
\hline & $200-400$ & 31 & 17 & 48 & $X^{2}=3.64$ \\
\hline & $401-600$ & 21 & 5 & 26 & $P$ value $=0.457$ \\
\hline & 601-1000 & 43 & 15 & 58 & \\
\hline & $>1000$ & 8 & 4 & 12 & \\
\hline & Total & 132 & 58 & 190 & \\
\hline Number of children & $1-2$ & 76 & 32 & 108 & \\
\hline
\end{tabular}


Knowledge, Attitude and Practice towards Exclusive Breast Feeding among Inhabitants of Ginjo Guduru Kebele, Jimma Town, Oromia Region, Ethiopia

\begin{tabular}{|c|c|c|c|c|c|c|}
\hline \multirow{4}{*}{\multicolumn{2}{|c|}{ 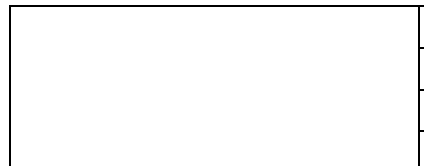 }} & 3- 4 & 52 & 20 & 72 & \multirow{4}{*}{$\begin{array}{c}X^{2}=6.28 \\
P \text { value }=0.099\end{array}$} \\
\hline & & $5-6$ & 4 & 4 & 8 & \\
\hline & & $>7$ & 0 & 2 & 2 & \\
\hline & & Total & 132 & 58 & 190 & \\
\hline
\end{tabular}

\section{DISCUSSION}

This study showed that the prevalence of exclusive breast feeding for infant age less than six months is $92.11 \%$. This result is quite higher than the finding from Mekele in 2011. (20), which was $60.8 \%$. Also this result is inflated compared to national prevalence which is $49 \%$. (15). The reason such gap might be related to the majority of mother's in the study area were educated and using mass media that help them to practice exclusive breast feeding. In addition the reason for this might be the current policy implementation on the use of health extension worker to promote breast feeding.

Concerning knowledge of EBF, This study also showed that majority of mothers had EBF knowledge, attitude and practice which is similar when compared with study in Kirkos sub city, 2011. (18).

The timely initiation of breast feeding found in this study was $85.26 \%$. This finding was high when compared to the study conducted in Asella town, 2009, 74.6\%. (19) and this difference might be because of high proportion of mother's awareness increment through mass media, health worker and books which could help them to initiate breast feed early. In this study mothers were asked about the frequency of breast feeding. The result showed that the appropriate frequency of breast feeding rate was $47.9 \%$. This is very much lower than $85.3 \%$ result in in Mekele town 2011 (20). This difference could be explained that in the current study, the majority of respondents work outside home by occupation, so they might have low chance of staying with their babies.

Regarding the time of cessation of breast feeding about $54.74 \%$ of the mothers said between 19- 24 months and most of them addressed the reason was they assume this time as adequate for weaning.

In Ethiopia, cross sectional survey (16). shows majority of mothers stop breast feeding when they became sick or pregnant or their child became sick. More than half of the women decide to discontinue breast feeding when become pregnant again (14). The reason majority of mothers stop adequacy of time secondary to information they got from health institution, mass media and books might.
Like in many other developing countries, the practice of mother giving water to their children in addition to the breast milk was common. It is evident that early introduction of liquids and solid is unnecessary, reduces the duration and frequency of breastfeeding, and increases risk of infant morbidity and mortality. $(23,24)$, and therefore such unhealthy behavior need to be corrected.

Knowledge is associated positively with age of the mothers, types of family, educational status and occupation of the mothers. Attitude of the mothers is related with type of family and occupation. Practice is also related with age of the mother and education. Regarding attitude, the research done in Santiago, California (14) is similar.

\section{Conclusion}

Though the knowledge and attitude of mothers toward EBF was encouraging, timely the gaps mainly appropriate rate and timely initiation in breast feeding practices were laid down according to this study. Also it was noticed from the study that occupation significantly associated with the attitude toward EBF and the literacy, occupational status level of mothers along type of family have association with knowledge. Beside age of mothers and their educational status have direct relation with Practice of EBF.

\section{RECOMMENDATION}

Health service delivery staffs, Policy makers, administrators and Non-governmental organization should collaborate to draw strategies to enhance the practice and timely initiation of mothers to breast feeding so that EBF achieved. Mothers who deliver in the health institute should have prior knowledge about EBF so that they initiated to breast feed their child including the time of initiation immediately after birth. The harmful effect of failure in exclusive breast feeding and similar large scale study should be conducted in regional and country level so that best strategies to achieve EBF practical in Ethiopia.

\section{REFERENCES}

[1] Aldine De Gruyter: Breast Feeding by Cultural perspective: new York, 1995

[2] WHO/UNICEF: Infant and young child feeding: Geneva, 1981 
[3] EDHS, 2005:145

[4] Black Re, Moris and Bryce: Where and why are 10 million children dying every year?

[5] United Nations Statistic Division: Progress Towards the Millenium Development goals: 1990- 2005 E http:UN.org/UNSD/mi/Goals 2005

[6] Central board of health Zambia: Central board Annula Health: Statistical bulletin,2003

[7] Jones G, Steketee Rw, Black Re, Bhutta ZA. Morris's How much child death can we prevent this year? 362:65-71

[8] Custodies A, Goga AE Rollins N, Coordia HM: Free Formula milk for infants of HIV-infected Women: Blessing or Curse? Health policy palm 2002, 17: 154-60

[9] Coovadia HM, Rollins Nc, Bhand Rm, little k, Custodious a, Bennish ML. Newll Ml: Mothers - To Child Transmission of HIV, infection during EBF in the first 6 months of life: an international cohort study lancet 2007, 369: 1107-16

[10] Black RE, Allen LH, Bhatta ZA, Caulfield LE, Deonis M, Ezzati M, Mothers C, Rilene J: Maternal and Child Under Nutrition: Global and Regional Exposure and health Consequences Lancet 2008, 371:243-60

[11] Bhandari N, Bahl R, Muzumdar S, Martnes J, Balck RE, Bhan MK: Effect of Community Based Promotion of EBF on Diarrhea illness and growth Cluster randomised controlled trial lancet 2003, 361:14118-23

[12] Adam BA, Perez-Escamill R, Latrey A: Lactation Counselling Increases EBF in; Ghana -J nutr 200 135: 1691-5

[13] Morrow AL, guerello ML, Shults J, Calva, lutter C, Bravo J, Ruiz-palacious G, Marrow RC, and butter Foss FD: Efficiency of home based peer counsellors on exclusive breast feeding practice in Dhaka Bangladesh: a randomised co.

[14] Norma Jean EICHE: Assessment of Attitudes tow ords breest feeding among WIC participants, Nov.-2000

[15] Division of child health and development evidence for the ten steps to successful breast feeding Geneva: WHO 1998
[16] Woldegabriel A. Mothers knowledge and beliefs on Breast feeding in Ethiopia med $\mathbf{J}$ 2002; 40;365-97 /midline/

[17] Abate G. Child Feeding practices and predictors of nutritional status of children in slum area AA Ethiopia EJHD, 2002

[18] Solomons (2011) Assessment of knowledge attitude and practice of exclusive breast feeling in Krikos sub city Addis Ababa, Ethiopia. Journal of health science, Vol 3(2): PP (7-11).

[19] Jemal H (2009). Knowledge, attitude and practice towards exclusive breast feeding in Asella town, Ethiopia. Journal of health science Vol 4(3): pp. (6-13).

[20] Hailemar -am B (2011). Determents of breast feeding practice among mothers of children aged less than 24 months in Mekele town, Ethiopia. Journal of health science Vol 3(2): PP (48-56)

[21] Bloss E, Wainaina F, Bailey RC. Prevalence and Predictors of Underweight, Stunting, and Wasting among Children Aged 5 and Under in Western Kenya. Journal of Tropical Pediatrics. 2004;50(5):260-70.

[22] Brunken GS, Silva SM, França GVA, Escuder MM, Venâncio SI. Risk factors for early interruption of exclusive breastfeeding and late introduction of complementary foods among infants in midwestern Brazil. Jornal de Pediatria. 2006;82(6):445-51.

[23] Shirima R, Greiner T, Kylberg E, GebreMedhin M. Exclusive breast-feeding is rarely practised in rural and urban Morogoro, Tanzania. Public Health Nutrition. 2000;4(2):147-54.

[24] Carvalhaes MAdBL, Parada CMGdL, Costa MPd. Factors associated with exclusive breastfeeding in children under four months old in Botucatu-SP, Brazile. Rev Latino-am 2007;15(1):62-9.

[25] Teshale Mulatu Dibisa Yitagesu Sintayehu. Exclusive Breast Feeding and Its Associated Factors Among Mothers of $<12$ Months Old Child in Harar Town, Eastern Ethiopia: A Cross-Sectional Study.

[26] Poreddi Vijayalakshmi, (1) Susheela T, (2) Mythili D (3). Knowledge, attitudes, and breast feeding practices of postnatal mothers: A cross sectional survey.

Citation: Habtamu Gebresenbet. Knowledge, Attitude and Practice towards Exclusive Breast Feeding among Inhabitants of Ginjo Guduru Kebele, Jimma Town, Oromia Region, Ethiopia. ARC Journal of Nutrition and Growth. 2020; 6(2):28-41. DOI: https://doi.org/10.20431/2455-2550.0602005.

Copyright: () 2020 Authors. This is an open-access article distributed under the terms of the Creative Commons Attribution License, which permits unrestricted use, distribution, and reproduction in any medium, provided the original author and source are credited. 